\title{
Survival Journalism in Disaster News Coverage (Case Study of Merapi Eruption Disaster 2010)
}

\author{
$1^{\text {st* }}$ Fajar Dwi Putra \\ Department of Communication Science \\ Universitas Ahmad Dahlan \\ Yogyakarta, Indonesia \\ dwiputra@fsbk.uad.ac.id
}

\author{
$2^{\text {nd }}$ Dani Fadillah \\ Department of Communication Science \\ Universitas Ahmad Dahlan \\ Yogyakarta, Indonesia \\ dani.fadillah@comm.uad.ac.id \\ $4^{\text {th }}$ Muhammad Najih Farihanto \\ Department of Communication Science \\ Universitas Ahmad Dahlan \\ Yogyakarta, Indonesia \\ najiholic@gmail.com
}

\author{
$3^{\text {rd }}$ Choirul Fajri \\ Department of Communication Science \\ Universitas Ahmad Dahlan \\ Yogyakarta, Indonesia \\ choirul.fajri@comm.uad.ac.id
}

\begin{abstract}
For some people, a disaster is something that is avoided, but not for a journalist, a disaster is a magnet in itself to do coverage from the closest distance. The profession as a journalist is at the forefront, between life or news, a tough choice and requires complete mental preparation. For this reason, psychological defensiveness for journalists is needed in covering themselves, especially disaster coverage. This research provides an overview of what journalists must prepare for disaster reporting, so that the soul will be stronger and the process of covering news will be much better. Merapi Eruption October 26,2010 was the biggest disaster in history after 1872. This cycle was called 1000 years of Merapi eruption.
\end{abstract}

Keywords - Disaster communication, Communication Psychology and Journalism

\section{INTRODUCTION}

As a journalist, news is a product that must be formed and packaged properly and fairly. The information provided is true data and can be accounted to the public. There have been a number of cases that occurred in covering disaster, ranging from poor self-defense in terms of personal security, information received and unpredictable field conditions. One thing that the author holds in carrying out the reporting process is "Nothing is more valuable than life." That principle makes writers and other journalists more careful in investigating disaster news, because in just a few seconds lives can be lost.

Merapi 2010, precisely 26 October for writers and other journalists is a challenge that must be endured. Many victims fell, infrastructure was destroyed and several education fields were badly damaged. The psychological condition of residents affected by the eruption of Merapi has gotten worse. Some journalists experienced traumatic due to the 2010 Merapi eruption.

At certain moments, journalists are required to do their jobs quickly, professionally and ready to deal with any type of conflict in the field. Journalists' readiness in reporting becomes very important in the field, be it electronic or printed journalists.

Even though some journalists are equipped with disaster knowledge, there are still many journalists who experience traumatic experience and even die due to self-defense strategies and cannot stand the conditions of the field, flying dust and heavy ash. Is this a form of company unpreparedness or a journalist who experiences psychological shocks while in the field?

\section{LITERATUR REVIEW}

To review the direction of this study, the authors use several theoretical basis to describe the situation. The author uses two approaches, the first is a psychological approach and the second is a journalistic approach.

A. Psychological Approach

- Laura explains that self-efficacy is someone's trust in their own abilities. [1]

- Jess Feits states that self-efficacy refers to an individual's belief in his ability to succeed in doing something. [2]

- Jeeffrey S. Nevid provides a view of self-efficacy is one's belief in his ability to master the situation and produce something beneficial. [3]

\section{B. Disaster Journalism Approach}

- Reporting activities related to disaster events that occur and recorded based on the date of the incident, location, type of disaster, victims or damage. If coverage takes place on the same date and more than one region occurs, then it is counted as one region. [4]

- Disaster journalism is a journalistic activity that helps the community and other parties in disaster management. [5]

\section{RESULT AND DISCUSSION}

The first thing is understanding the basis for thinking, theorizing and behaving describing a regional boundary of events and ignoring other influences, or estimating them with certain numbers. [6] Referring to the view of psychoanalysis, humans tend to seek pleasure and avoid anxiety. When anxiety occurs, the individual will use the ego defense mechanism to reduce the level of anxiety, including; Normandism is a defense mechanism to escape from reality. In using this defense, a person tries to reduce anxiety by physically removing himself from threats. Normandism can be used to 
reshape, but if done excessively can have tragic consequences. [7]

One terrible preparation is asking for family permission for disaster reporting. The author experiences a dilemma that can eventually be resolved by communication techniques. This technique is called speech and logic. For example, "Allow me coverage to Merapi, moreover this is a humanitarian task." From there the correct communication techniques are carried out when facing an emergency situation. Because, for anyone, family is important, with the permission of the family, the concept of psychological selfdefense will be stronger. [8]. Because, the world needs more family love. [9]

Breaking away from the threat of disaster is something that is perfectly natural to happen. But, in this condition, the writer (when experiencing firsthand in the field) has no other choice but to continue to defend himself to take the actual news from a closer perspective or at least harmless. In this position there is an inner battle that you have between your soul and your duties and responsibilities as a journalist.

Here, the writer performs psychological role communication. What is meant by role communication is to determine how much active participation or contribution someone is given in one conversation situation. [10] The conversation in question is with residents affected by the 2010 Merapi eruption, Kinahrejo. Role playing can combine the use of certain techniques. [11]

The happy concept that is sought in the management of self-defense in disaster environments. Because the diagnosis in humans can be started from the recognition of Schopenhauer who said that human happiness depends on its existence and not on the surrounding environment. [12] When doing coverage, the writer has conceptualized happiness in himself to prepare in the field.

There is a dualism that occurs when covering, between fighting fear or hiding. There are only two choices, this condition is called the destructive dilemma of a conditional premise dilemma concluded from a consequence of the same antecedent. If one means the consequence is wrong, then the antecedent is wrong. Similarly, if I feel defeated in coverage, then what happens is the feeling of surrender, and that is bad in times of disaster. [13]

The author found experiences that can be discussed through this paper. Clear preparation must be done with the assumption that humans have a good cognitive component. The component consists of cognitive, affective and conative components. Unique facts are displayed in the cognitive component that says a person's beliefs about what is valid or what is true for objects and attitudes. [14] This is true, because the author feels the same about the concept of belief about a safety in the field, because trust comes from what we have seen or what we already know. Based on what we know and see, then an idea or idea is formed about the nature or general character of an object.

There is a feeling of fear to see open space, in psychological terms, this is called Agrophobia. Because, the condition of Merapi at that time was really terrible. [15]. There is what is called the concept of unconsciousness in the psychoanalytic view, this is what ultimately changes human understanding of themselves, even with this concept ultimately changing the way humans view their world. [16]

A condition that is very difficult, so researchers must take action by considering this as a cognitive challenge. In communication logic, cognitive challenges are thoughts that are weakly linked to deal effectively with inherent uncertainty and induce uncertainty. The choice must be made, so that a decision must occur in doing the work. [17]. In humans there are two positive and negative energy pulls that lead people to decide all forms of communication and behavior in the field and all of them will have an impact on the condition of each human being. [18]. When someone is able to provide positive energy within, then what happens is the appearance of the light of nature, emitting the color of nature or the sacred and become sacred. This fact of nature is related to the honesty of self-communication in the field, because humans with all their fitrah are honest, and honesty is the light when humans are in the midst of a turbulent universe. [19]. Because at that time the author was faced with situations that are visible and not visible. The invisible (non-material power) is present in the visible. Non-material power is potential compared to imitation. [20]

Our awareness of theoretical assumptions that are owned and their imperfect nature, may be generated by any experience in which established habits become unjustified. [21]. Assumptions that occur in the field are concrete, unclear because of psychological, sociological conditions that are very worrying for their respective souls. So, what the authors do is maintain the assumption that the writer must stay afloat and think clearly about field conditions.

This condition of Normandism, according to the author, is the initial condition of a journalist in reporting news in the disaster area.

The author as a journalist who immediately experienced the terrible event convinced himself when the Normandism phase occurs, then the phase of Sympathism will follow. And it really happened, the writer felt failed in taking the news because the conditions or places that are usually good for the camera angle have been destroyed. The author is faced with two choices of truth, between news and information that are both true or choose one that is useful, namely backward. This condition is called disjunction, a statement that at least one of the two proportions of the correct choice. [22]

This is normal, because in uncomfortable conditions, various assumptions or thoughts often arise to end all this confusion. Intellectualization is a person's mental condition when in an unpleasant emotional position, someone is trying to eliminate these emotions by thinking logically. [7]

This means that with a simple analogy the writer wants to convey, at that time the writer was faced with two difficult situations. Between yes and no. When the writer thinks "No" then what happens is emotional, then when thinking "Yes" there is a kind of rational psychological impulse to continue to survive in an unfavorable position. Because there are only dead bodies and very dusty conditions.

In such conditions, it is feared that carelessness in taking a stand will emerge. The intended frivolity is; cowardly, badtempered, hard, rude and arrogant. [23] There is a method in the study of psychology of communication called the selfdeterrence method. In this method, it is explained how the 
communicator releases from responsibility for violating certain social norms. In this case it is associated with the adat norms of the Merapi area and work norms. [24]

If we pull back, there are various kinds of human mental conditions when faced with such a position. Referring to basic human needs, Maslow once said healthy people like work rather than unemployment, but most people choose not to work rather than doing things that are not useful. [25] This condition if applied to the status of a disaster, then the writer chooses to work rather than unemployed, meaning that there are responsibilities that must be resolved.

One of the things that must be done when covering a disaster is how to keep the mind stable seeing the appalling field conditions. The stabilization of the mind is called the concept of anapanasati or concentration of mind, it is quite difficult, but this condition can be done if the soul is calm and not panic. [26] These conditions can be influenced by lifestyle. The author acknowledges that the lifestyle that is carried out is very influential on the psychological condition when carrying out the Merapi 2010 execution. Lifestyle is not only influenced by intrinsic interests, but through an observation. [27] Added to that was the condition that was not conducive.

If the soul has calmed down, the coverage process will go well. So humans can be more sensitive listening to the sound of Mount Merapi, which is very powerful. This communication condition called perceptions of spatial location or neurons can selectively distinguish arrival times from sounds in the right and left ears. And perception of Environmental sound. Three main functions of hearing in humans are to detect sound, determine the location of sound sources and identify sound patterns. [28]. So what happens is the concept of thinking win to win. In an emergency, such a mindset is very beneficial for the writer, the impact that occurs is the emergence of a great enthusiasm to complete the task. Winning is a belief in the third alternative, this is not a way for the writer or the community, but this is a better way. [29]

Collective thinking is formed not because of the existence of individual thought, but because of the constellation or relationship between individual thoughts. [30]. When disaster strikes, it takes a way to look at the situation carefully, thoroughly and thoroughly. In the contribution of communication, there is a concept called Arete or the ability to look closely or functional perfection in everything. [31]. A belief is needed in full in maximizing disaster behavior, this concept is called the actualization of the belief that a belief can be justified and argued. There is no way to show the relevance of beliefs to reality. [32]. It means that when the writer does the coverage in the field there is a kind of doubt to decide to go up to a more dangerous place, there, the writer is confronted with reality and beliefs about himself and life.

In this context, humans are consistent participants to enable to find their own reality to negate themselves in the sense of self negation. On the other hand, there is no human characteristic that is more unique and singular than human consciousness as a "me", as a unique solitude. Thus, human consciousness as a self and I can be seen as the origin of the ambiguity of human existence. [33].

\section{CONCLUSION}

Self-defense is basically needed to provide a sense of security, calm and pleasure so that what is the goal will be achieved properly. One thing that is needed by humans is mental preparation, several stages of self-defense and defense mechanisms in the disaster area.

Logical reasoning is when a person goes through all stages of self-defense then it is certain to have a minimum level of anxiety, even though someone who has a minimum level of anxiety may not be able to pass the stage of self-development properly, because it is possible that the excesses generated from obstacles that occur cause psychological deviations that occur produce an individual without the expression of anxiety or fear, especially if the individual is good at hiding behind the defense mechanism.

\section{REFERENCES}

[1] Laura A. King, Psikologi Umum. Jakarta Selatan: Penerbit Salemba, 2016.

[2] G. J. F. Jess Feist, Theories of Personality, Keenam. Yogyakarta: Pustaka Pelajar, 2008

[3] B. G. Jeffrey S. Nevid, Spencer A. Rathus, Psikologi Abnormal, Kelima. Jakarta: Penerbit Erlangga, 2003.

[4] S. Fajar Junaedi, Filosa Gita, Jurnalisme Sensitif Bencana "Panduan Peliputan Bencana.” Yogyakarta: Buku Litera Yogyakarta, 2017.

[5] Jerry E. Smith, Konspirasi Bencana Alam. Jakarta Selatan: Phoenix Publishing Project, 2013.

[6] Stephen W. Hawking, Teori Segala Sesuatu, Keempat. Yogyakarta: Pustaka Pelajar, 2016.

[7] Saludin Muis, Kenali Kepribadian Anda dan Permasalahannya. Yogyakarta: Graha Ilmu, 2009.

[8] Oh Su Hyang, Bicara Itu Ada Seninya. Rahasia Komunikasi Yang Efektif., Ketiga. Jakarta: Bhuana Ilmu Populer, 2018.

[9] P. D. Jack Canfield, Mark Victor Hansen, Mark \& Chrissy Donnelly, Barbara De Anggelis, Chicken Soup for The Couple's Soul. Jakarta: PT. Gramedia Pustaka., 2001.

[10] M. S. Dr. Yayah Nurhidayah, M. Si, Prof. Dr Eti Nurhayati, Psikologi Komunikasi Antar Gender. Yogyakarta: Pustaka Pelajar, 2018.

[11] D. G. Kathryn Geldard, Konseling Remaja, Satu. Yogyakarta: Pustaka Pelajar.

[12] Zainal Abidin, Filsafat Manusia "Memahami Manusia Melalui Filsafat," Delapan. Bandung: PT Remaja Rosdakarya, 2017.

[13] Zainul Maarif, Logika Komunikasi, Kedua. Jakarta: PT Grafindopersada, 2016.

[14] M. A. Dr. Saifuddin Azwar, Sikap Manusia. Teori dan Pengukurannya, Kedua. Yogyakarta: Pustaka Pelajar, 2016

[15] Alex Sobur, Kamus Psikologi, Satu. CV Pustaka Setia, 2016.

[16] P. Siswanto, S. Psi., M.Si., Psikologi Kesehatan Mental. Yogyakarta: Penerbit Andi OFFSET, 2015.

[17] J. Richards J. Hever, Psikologi Intelijen, Ketiga. Yogyakarta: Ar-Ruzz Media, 2016.

[18] Nashir Fahmi, Spiritual Excellence. Jakarta: Gema Insani, 2009.

[19] Muhyiddin Hairi Shirazi, Tikai, Ego dan Fitrah. Jakarta: Penerbit AlHuda, 2010

[20] Jakob Sumardjo, Etika Paradoks, Pertama. Bandung: Sunan Ambu Press, 2006

[21] Doyle Paul Johnson, Teori Sosiologi Klasik dan Modern. Jakarta: PT. Gramedia Pustaka., 1986.

[22] Simon Blackburn, Kamus Filsafat, Kedua Revi. Yogyakarta: Pustaka Pelajar, 2013.

[23] Imam Fakhruddin Ar-Razi, Kitab Firasat. Jakarta Selatan: Turos Pustaka, 2017

[24] M. A. Morissan, Psikologi Komunikasi, Kedua. Bogor: Ghalia Indonesia, 2013

[25] Frank G. Goble, Mazhab Ketiga Psikologi Humanistik Abraham Maslow. Penerbit Kanisius, 1987.

[26] Tjiptadinata Effendi, Never Ending Meditation. Jakarta: PT Elex Media Komputindo, 2007.

[27] Alwisol, Psikologi Kepribadian, Pertama. Malang: UMM Press, 2009. 
[28] M. S. Iriani Indri Hapsari, M. Psi, Dr. Ira Puspitawati, M.SI, Ratna Dyah Suryaratri, Psikologi Faal. Bandung: PT Remaja Rosdakarya, 2017.

[29] Stephen R. Covey, The 7 Habits of Highly Effective People, Kedua. Jakarta: PT Dunamis Intra Sarana, 2015.

[30] J. Jaelani Yasraf Amir Piliang, Teori Budaya Kontemporer. Aurora, 2018
[31] Zainul Maarif, RETORIKA Metode Komunikasi Publik. Jakarta: PT Grafindopersada, 2017.

[32] A. A. Yazdi, Sejarah Skeptisisme "Jatuh Bangun Paham Keraguan atas kebenaran.," Satu. Jakarta: Sadra Internasional Institute, 2016.

[33] Fuad Hassan, Psikologi, Kita dan Eksistensialisme. Pengantar Filsafat Barat, Berkenalan dengan Eksistensialisme, kita dan Kami., Satu. Depok: Komunitas Bambu, 2014. 